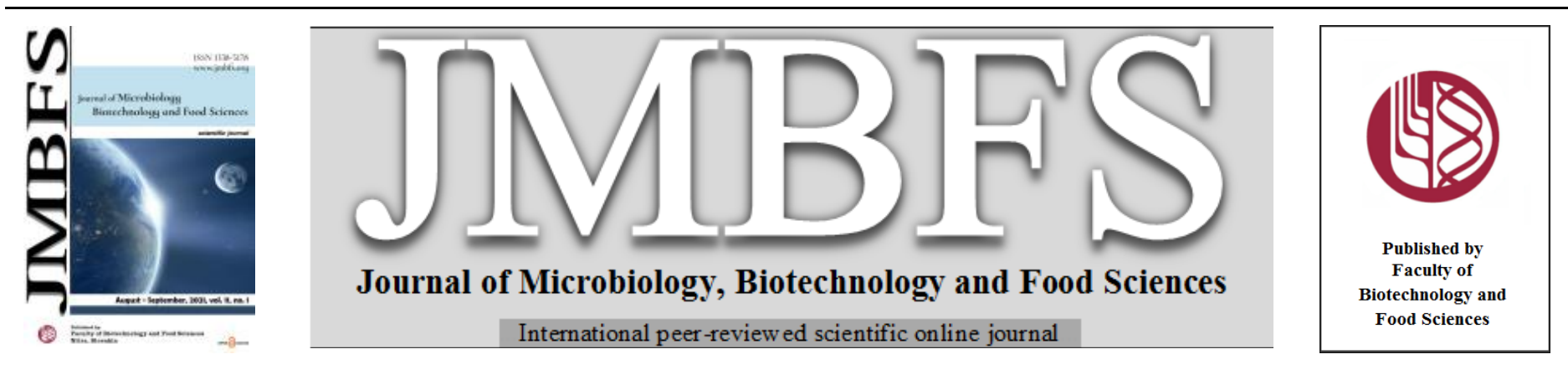

\title{
IMPACT OF SALT REDUCTION ON BREAD ON SENSORY PREFERENCE AND PHYSICOCHEMICAL PARAMETERS
}

\author{
C. Monteiro ${ }^{a}$, Z. E. Martins ${ }^{b}$, O. Pinho ${ }^{a, b}$, C. Gonçalves ${ }^{a, c, d^{*}}$
}

Address(es):

${ }^{\text {a }}$ Faculdade de Ciências da Nutrição e Alimentação da Universidade do Porto, 4200-465 Porto, Portugal.

${ }^{\mathrm{b}}$ LAQV/REQUIMTE, Laboratório de Bromatologia e Hidrologia, Departamento de Ciências Químicas, Faculdade de Farmácia, Universidade do Porto, 4051-401 Porto, Portugal.

${ }^{\mathrm{c}}$ CIAFEL, Research Centre in Physical Activity, Health and Leisure, Faculty of Sport, University of Porto, 4200-450 Porto, Portugal.

${ }^{\mathrm{d}}$ CITAB, Centre for the Research and Technology of Agro-Environmental and Biological Sciences, 5000-801 Vila Real, Portugal.

*Corresponding author: carlagoncalves.pt@gmail.com

https://doi.org/10.15414/jmbfs.2701

\section{ARTICLE INFO}

Received 27. 2. 2021

Revised 12. 2. 2021

Accepted 16. 2. 2021

Published 1. 8. 2021

Regular article open $\bigodot_{\text {ACCESS }}$

\begin{abstract}
Purpose

The purpose of this study was to evaluate the impact of salt reduction on bread physicochemical parameters and sensory analysis. The relationship between sensory attributes and preference was assessed using external preference mapping (PREFMAP). Moreover, sensory attributes relationship with physicochemical parameters was evaluated.

Methodology

Four Portuguese bread formulations were tested: "D'água", "Carcaça", "Mistura", and "Regueifa", produced with different salt concentrations $(0.0 \%, 0.8 \%, 1.0 \%, 1.1 \%, 1.3 \%$, and $1.4 \%$ of salt per wheat flour). Bread physicochemical characteristics evaluated included weight, volume, moisture, salt content, and crumb colour and structure. Sodium was determined by flame photometry method, while crumb colour and structure by digital image analysis. Sensory analysis was carried out with 8 trained assessors and consumer test with 80 participants. Statistical models for sensory preference evaluation were developed using PREFMAP. Statistical comparison was performed using as control bread with $1.4 \%$ of salt (legal value allowed).

Findings

Overall, salt reduction had significant impact on moisture, salt content and colour parameters, but limited influence on crumb morphology. Salt reduction had a significant negative impact on overall assessment, taste liking and overall linking attributes. The lowest salt concentrations with best consumer acceptance were: $0.8 \%$ ("D’Água" and "Carcaça"), 1.0\% ("Mistura"), and 1.1\% ("Regueifa"). These results suggest that salt reduction in these breads is possible without major impact on bread characteristics and without compromising consumers' acceptance.
\end{abstract}

Keywords: bread; salt; sensory analysis; image analysis; external preference mapping

\section{INTRODUCTION}

High sodium intake has been widely pointed as the most important factor for high blood pressure, that's closely associated to increased risk of cardiovascular diseases and stroke (Poggio et al., 2015). Therefore, the World Health Organization (WHO) recommended a reduction of sodium intake to $<2000 \mathrm{mg}$ per day, approximately $5 \mathrm{~g}$ of salt per day (WHO, 2012). However, global estimates of salt intake largely exceed recommendations (Powles et al., 2013). In Portugal, mean salt intake in adult population is approximately twice as high as recommendations (Polónia et al., 2014).

Bread is a staple food of the diet, and due to its high consumption, is an important contributor to dietary sodium intake (Belz et al., 2012). According to the last National Food, Nutrition and Physical Activity Survey developed in Portugal to collect national and regional data on dietary habits in a representative sample of the population, the second major contributor for sodium intake of the population was the group of bread and toasts (18.0\%) (the first was the table salt) (Lopes C et al., 2018). Following the Framework for National Salt Initiatives created by European Union, several countries have developed operational salt reduction programs, where bread is one of the priority foods to intervene (European Union, 2009). In Portugal, a national legislation concerning salt content in bread set a maximum of $1.4 \mathrm{~g}$ of salt per $100 \mathrm{~g}$ of bread (Assembleia da República, 2009). Nevertheless, considering its importance on diet, any further reduction of salt content is expected to have a significant impact on heath.

However, salt has specific properties that are essential for bread processing and final product quality. Salt acts as a: preservative, by decreasing water activity and promoting shelf life; yeast fermentation modulator, by reducing gas production rate, promoting a stronger inter-protein hydrophobic interactions, strengthening the gluten network and enhancing dough stability, improving texture of the final product (Man, 2007).

Moreover, salt plays a significant role on bread sensory properties, acting as a flavour modifier and influencing crust development and crumb structure (Belz et al., 2012; Silow et al., 2016). Therefore, despite their health benefits, breads with salt reduction must have high sensory acceptance in order to compete with traditional bread formulations. External preference mapping (PREFMAP) is a useful statistical method to examine individual consumers' acceptability and relate it to sensory, physical and/or chemical data (Greenhoff $\boldsymbol{\&}$ MacFie, 1994). Moreover, this method based on principal component analysis, hierarchical clustering, and polynomial regression, takes into consideration heterogeneity in acceptability among consumers. Partial least squares (PLS) regression is another valuable statistical method for analysing or predicting a set of dependent variables from a set of independent variables (predictors). Therefore, statistical methods can be useful tools for sensory preference evaluation and correlation with physicochemical parameters.

For these reasons, reduction of salt in the bread formulation is paramount, but remains a major challenge for the baking industry to achieve it without impact on the technological functions and baking performance, and understand the influence of salt reduction on consumers' acceptance. Therefore, this study aimed to evaluate the impact of salt reduction on: (i) physicochemical parameters; (ii) on sensory analysis, using a trained panel and consumers group; and (iii) the relationship between sensory attributes and physicochemical parameters in four types of Portuguese traditional breads. 


\section{MATERIALS AND METHODS}

\section{Sampling}

Samples of four types of Portuguese traditional breads, namely "D'água", "Carcaça", "Mistura", and "Regueifa" were produced in an experimental laboratory of Ceres (Porto, Portugal), under controlled conditions (humidity/temperature). In the original bread recipes used by bakeries only salt addition in manufacture was known but not the amount present in final product; therefore, a preliminary study was carried out to determine it. Those values were then used to estimate the required quantity to obtain a bread with $1.4 \mathrm{~g}$ of salt/100 $\mathrm{g}$ of bread that was considered as control bread $(1.4 \%$, considered as control bread) ) as well as breads with salt reduction (\% of salt per wheat flour): $0.0,0.8$, $1.0,1.1,1.3$, and 1.4. Ingredients used in the production of bread samples (flour, water, fresh yeast, commercial powder improver, and salt) were supplied by Ceres. Fresh yeast was obtained from a pure culture of Saccharomyces Cerevisiae
(FALA AZUL, Lasafree Ibérica S.A., Valladolid, Spain), with a fermentative power of the $135 \mathrm{~cm}^{3} \mathrm{CO}_{2} / 2 \mathrm{~h}$. The powder improver contained acidity regulator (E170i, E341), emulsifier (E472), wheat flour, antioxidant (E300), and enzymes (Cerpan, Ceres, Portugal)

\section{Bread Making}

All samples from each type of bread were produced under the same conditions of humidity and temperature, using industrial machines: mixer, fermentation chambers and ovens (Sopaco, Rio Tinto, Portugal).

Each bread type was produced according to original recipes and specific technological details as shown in Table 1 . Every bread was cooled at room temperature during $90 \mathrm{~min}$ before further analysis. Additionally, samples were frozen before sodium analysis.

Table 1 Original recipes of the different bread types in study, salt reduction levels, and specific technological details

\begin{tabular}{|c|c|c|c|c|c|c|c|c|c|}
\hline \multirow[b]{2}{*}{$\begin{array}{l}\text { Type of } \\
\text { bread }\end{array}$} & \multicolumn{5}{|c|}{ Ingredients } & \multicolumn{4}{|c|}{ Technological Process } \\
\hline & Flour type & $\begin{array}{l}\text { Water } \\
(\%)^{*}\end{array}$ & $\begin{array}{l}\text { Yeast } \\
(\%)^{*}\end{array}$ & $\begin{array}{l}\text { Powder } \\
\text { improver } \\
(\%)^{*}\end{array}$ & $\begin{array}{l}\text { Salt levels } \\
(\mathrm{g} / 100 \mathrm{~g})\end{array}$ & Kneading & Dough portions & Proofing & Baking \\
\hline "D’água" & $\begin{array}{l}\text { Mixture of } 70 \% \text { of type } 65 \text { wheat } \\
\text { flour, } 25 \% \text { of type } 80 \text { wheat flour, } \\
\text { and } 5 \% \text { of type } 70 \text { rye flour }\end{array}$ & 80 & 3 & 1 & $\begin{array}{l}1.4 ; 1.3 ; 1.1 \\
1.0 ; 0.8 ; 0.0\end{array}$ & $25 \mathrm{~min}$ & $\begin{array}{l}65 \mathrm{~g} \text {; shaped into } \\
\text { balls; refrigerated } \\
\text { for } 60 \mathrm{~min}\end{array}$ & $\begin{array}{l}\mathrm{RT} ; 30- \\
90 \min ^{1}\end{array}$ & $\begin{array}{l}200{ }^{\circ} \mathrm{C} ; \\
30 \mathrm{~min}\end{array}$ \\
\hline "Carcaça" & Type 65 wheat flour & 60 & 5 & 1 & $\begin{array}{l}1.4 ; 1.3 ; 1.1 \\
1.0 ; 0.8 ; 0.0\end{array}$ & $20 \min$ & $\begin{array}{l}65 \mathrm{~g} \text {; shaped into } \\
\text { balls }\end{array}$ & $\begin{array}{l}30^{\circ} \mathrm{C} \\
60 \mathrm{~min}\end{array}$ & $\begin{array}{l}200{ }^{\circ} \mathrm{C} ; \\
10 \mathrm{~min}\end{array}$ \\
\hline "Mistura" & $\begin{array}{l}\text { Mixture of } 79 \% \text { of type } 65 \text { wheat } \\
\text { flour, } 20 \% \text { of type } 70 \text { rye flour } \\
\text { and } 1 \% \text { of barley flour }\end{array}$ & 75 & 3 & 1 & $\begin{array}{l}1.4 ; 1.3 ; 1.1 \\
1.0 ; 0.8 ; 0.0\end{array}$ & $25 \mathrm{~min}$ & $\begin{array}{l}70 \mathrm{~g} \text {; shaped in } \\
\text { balls rested at } 30 \\
{ }^{\circ} \mathrm{C} ; 30 \mathrm{~min}\end{array}$ & $\begin{array}{l}\mathrm{RT} ; 90 \\
\min ^{1}\end{array}$ & $\begin{array}{l}220^{\circ} \mathrm{C} ; \\
30 \mathrm{~min}\end{array}$ \\
\hline "Regueifa" & $\begin{array}{l}\text { Mixture of wheat flour, vegetable } \\
\text { oil palm powder and milk protein }\end{array}$ & 50 & 3 & 1 & $\begin{array}{l}1.4 ; 1.3 ; 1.1 \\
1.0 ; 0.8 ; 0.0\end{array}$ & $13 \mathrm{~min}$ & $\begin{array}{l}500 \mathrm{~g} ; \text { pressed in } \\
\text { a dough sheeter; } \\
\text { shaped manually }\end{array}$ & $\begin{array}{l}30^{\circ} \mathrm{C} \\
60 \mathrm{~min}\end{array}$ & $\begin{array}{l}200{ }^{\circ} \mathrm{C} ; \\
10 \mathrm{~min}\end{array}$ \\
\hline
\end{tabular}

* Percentages applied to the total flour used RT, room temperature, ${ }^{1}$ For this bread type, proofing was carried out before cutting dough portions

\section{Bread Physicochemical Analysis}

\section{Bread weight, specific volume, and moisture}

Ten bread samples of each type of bread and salt content were individually evaluated for weight, specific volume, and moisture $(\mathrm{n}=10)$, except "Regueifa" bread, for which four samples were analysed $(\mathrm{n}=4)$.

Bread weight was evaluated in a digital scale METO (Esselte Meto International GmbH, Hirschhorn, Germany).

Bread specific volume (SV) was measured using a seed displaced method and the following formula

$\mathrm{SV}\left(\mathrm{cm}^{3} \mathrm{~g}^{-1}\right)=\frac{\mathrm{S}(\mathrm{g}) \times 1.35\left(\mathrm{~cm}^{3} \mathrm{~g}^{-1}\right)}{\mathrm{P}(\mathrm{g})}$

(1)

where $\mathrm{P}$ is the bread weight, $\mathrm{S}$ is the weight of displaced seeds, and 1.35 is the specific volume of Phalaris canariensis seeds (Martins et al., 2015). Bread moisture was done with moisture balance (KERN DLB 160-3A, Ziegelei, Germany) according to official methods (AACC International, 1999), at $130{ }^{\circ} \mathrm{C}$ Sample readings were made in triplicate.

\section{Sodium analysis}

Bread samples were analysed by flame photometry, carried out according to Vieira and co-workers (2012). Briefly, $2 \mathrm{~g}$ of sample (grounded and homogenized) were directly weighed in a $50 \mathrm{ml}$ tube and $4 \mathrm{ml}$ of nitric acid $\left(\mathrm{HNO}_{3}\right)$ (Fluka, France) were added. The mixture was shaken every $10 \mathrm{~min}$ for $60 \mathrm{~min}$. The volume was completed up to $45 \mathrm{ml}$ with deionized water and a preparation was homogenized using a Ultra Turrax blender (Ultra Turrax blender T25, Sotel, Germany). Calibration curves were established daily from standard sodium solutions with concentrations of $0.2,0.5,1.0,1.5$, and $5.0 \mu \mathrm{g} / \mathrm{ml}$ (Fluka, France).

\section{Crumb structure and colour image analysis}

For crumb structure and colour image analysis, three breads of every formulation were cut in slices of $1.6 \mathrm{~cm}$ thickness and analysed. Each slice was analysed in pre-standardized conditions: positioned on the flatbed scanner and a black cardboard was placed over the slice in order enhance contrast. Images were captured in the RGB (24 bit) standard format with a resolution of $300 \mathrm{dpi}$ and saved in JPG format. Each image was processed and analysed using Matlab R2015a (MathWorks) as described by Martins and co-workers (2017). Briefly, a single $300 \times 300$ pixel $(51 \times 51 \mathrm{~mm})$ field of view (FOV) was cropped, converted to a 256 level grey scale and segmented. Cell morphological parameters were analysed and recorded values for crumb structure were used to divided cells into different classes as a function of their area: very small size (cell area $\leq 0.2 \mathrm{~mm}^{2}$ ); small size $\left(0.2 \mathrm{~mm}^{2}<\right.$ cell area $\left.\leq 3.0 \mathrm{~mm}^{2}\right)$; medium size $\left(3.0 \mathrm{~mm}^{2}<\right.$ cell area $\leq 10.0 \mathrm{~mm}^{2}$ ); large size (cell area $>10.0 \mathrm{~mm}^{2}$ ).

To study the crumb colour, for the second approach, each single FOV obtained from bread image analysis was converted from RGB to CIElab system using a code written in Matlab R2015a (MathWorks). Furthermore, crumb L*, a* and b* values were combined in the browning index (BI) parameter (Buera et al., 1985) according to equations 2 and 3

$$
\begin{aligned}
& \mathrm{BI}=\frac{100(\mathrm{X}-0.31)}{0.172} \\
& \mathrm{X}=\frac{\mathrm{a}^{*}+1.75 \mathrm{~L}^{*}}{5.645 \mathrm{~L}^{*}+\mathrm{a}^{*}-3.012 \mathrm{~b}^{*}}
\end{aligned}
$$

\section{Bread Sensory Analysis}

In order to reduce salt in each bread type while maintaining consumers' acceptability, the study was structured into 3 steps. Firstly, sensory profile was evaluated in order to understand the influence of salt reduction on sensory characteristics of each bread type. Secondly, consumer acceptability regarding different liking attributes was assessed. Lastly, information gathered from the previous steps i.e., sensory vocabulary from descriptive analysis and hedonic data, was used to build a prediction model to explain consumer 's preference.

\section{Descriptive sensory analysis - trained panel}

Sensory profile was evaluated in order to understand the influence of salt reduction on sensory characteristics of each bread type. A sensory panel composed by 8 members was trained according to the guidelines in the ISO 8586 (2012).

Firstly, a descriptive vocabulary was developed with the assessors, who compiled a list of bread attributes. Training was carried out in two and redundant descriptive terms were removed. Sensory attributes were classified based on four characteristics, as shown in Table 2: appearance (visual perception), odour (olfactory perception), texture (tactile and oral texture) and flavour (oral and retronasal). Fifteen attributes were defined for bread descriptive sensory analysis: crust colour intensity, crumb colour intensity, number of large cells, number of small cells, odour intensity, crunchy crust, cohesiveness, adhesiveness, crumb elasticity, shape recovery, salty, sweet, bread aroma, aftertaste, and overall assessment (Table 2). Throughout two sessions, a score card was developed to evaluate attributes intensities using a 1-7 unstructured scale (1 representing the lowest intensity and 7 the highest intensity) and ballot anchors were established for each selected attribute. The bread sample used as control, 20\%, was select because it represented the midpoint of salt reduction range used in this study. In the evaluation sessions all breads and salt reductions $(0 \%, 10 \%, 20 \%, 30 \%$, $40 \%$, and $100 \%$ ) were assessed. Samples were presented in similar conditions: at 
room temperature and similar size, with approximately $7 \mathrm{~g}$ (a slice with $1.5 \mathrm{~cm}$ of thickness), including crust and crumb, in a random three-digit coded covered glass dish. These sessions were carried out individually under white light at room temperature. Assessors were provided with mineral water and instructed to cleanse their palate between tastings. All bread samples were analysed in triplicates, over six sessions.

Table 2 Descriptive sensory attributes developed by trained sensory panel

Sensory attributes
Appearance Definitions

Crust colour intensity

Degree of colour darkness in the crust - light to dark

Crumb colour intensity

Number of Large Cells

Number of Small Cells

Cell circularity

Cell homogeneity

Degree of colour darkness in the crumb - light to dark

Amount of large cells - low to high

Amount of small cells - low to high

Level of perfection of the circular shape of the crumb cells/ number of circular crumb cells Homogeneity of the size of the crumb cells

\section{Odour}

Odour intensity

Degree of intensity of odour of the sample - low to high

Texture

Crunchy crust

Degree of perceived noise when chewing the crust sample

Cohesiveness

Adhesiveness

Crumb elasticity

Shape recovery

Level of mass formation in the mouth before breaking

Degree in which the material adheres to the palate

Ability to return to initial shape after being pressed

Resistance to the crumb pressure on the finger

Aroma

Salty

Sweet

Bread aroma

Aftertaste

Perception of taste sensation for sodium chloride

Perception of taste sensation for sugars

Degree of perception of the intensity of the characteristic bread flavour

Flavour remaining after tasting

\section{Consumer test}

To evaluate consumer acceptability for bread with different salt levels, the sensorial acceptance hedonic test was applied to students, professors and employees of the University of Porto Campus that demonstrated interest to participate. Eighty consumers (53 women and 27 man, with 18-58 years old) participated in the trial and were divided in 4 groups of $20(n=20)$, with equal representation. Each type of bread and its respective salt concentrations was evaluated by a group of consumers. Therefore, six samples of bread were presented to each consumer in random three-coded plastic dishes. Acceptability tests were conducted using a hedonic scale of 7 points ( 1 corresponds to "dislike extremely" and 7 to "like extremely"), to assess the five following attributes: appearance liking, aroma liking, taste liking, texture liking and overall liking. Consumers were provided with mineral water and instructed to cleanse their palate between tastings.

\section{Preference Mapping}

The external preference mapping (PREFMAP) consists of a regression method used to map consumers' acceptability (hedonic ratings) onto the assessors' space (sensory profile) and obtain the sensory properties that influence consumer's preference. PREFMAP includes three sequential steps: create the sensory map, group the consumers, and create the preference. PCA was applied on sensory data of attributes evaluated by the trained panel to create the sensory map Considering overall liking attribute, consumers were grouped into homogeneous groups according to their preference, using Agglomerative Hierarchica Clustering (AHC). PREFMAP method was employed using the sensory attribute coordinates in the two-dimensional facto space, resulting from PCA, and average overall liking scores for each 3 clusters, obtained from AHC. As result, four different regression models were tested to predict each consumer group overall liking: i) vector model, where vector indicates the direction to increase acceptability of the sample in the map; ii) circular model, where ideal points (location of the most preferred sample) or anti-ideal points location of the least preferred sample) are obtained; iii) elliptical model; and iv) quadratic surface method. The last two models allow to obtain a maximum or minimum preference points, and also saddle points, which however, are seldom used as they are the most difficult to interpret and are not optima (Greenhoff \& MacFie, 1994; Martins et al., 2017).

Statistical Analysis

Parametric analysis was carried out by one-way ANOVA followed by Dunnett's (two sided) and non-parametric test by Kruskal-Wallis followed by Dunn's test.

Overall acceptability from consumers was also used to select the highest salt reduction with best sensory performance for each bread type studied. Sensory data collected was treated using External Preference Mapping technique.

PLS regression was also used to study the relationships between sensory attributes (Y-matrix) and physicochemical parameters, colour and crumb structure (X-matrix) in terms of prediction of $\mathrm{Y}$-variables from $\mathrm{X}$-variables. Random cross validation was also applied to identify relevant $\mathrm{X}$-variables.

All statistical analyses were conducted with the XLSTAT for Windows version 2016.02 (Addinsoft, Paris, France) at 10\% (External preference mapping) and 5\% (ANOVA, Kruskal-Wallis, and PLS regression) significance level.

\section{RESULTS AND DISCUSSION}

\section{Bread physicochemical characteristics}

The parameters determined to evaluate physicochemical characteristics of each bread type with different salt reduction are presented in Table 3.

Considering bread physical characteristics, the impact of salt reduction differed between bread types. Moreover, no linear pattern $\left(\mathrm{R}^{2}<0.700, \mathrm{p}>0.050\right)$ was observed, except for specific volume $\left(\mathrm{R}^{2}=0.953, \mathrm{p}=0.001\right)$ in "Carcaça", where specific volume values decreased as the salt reduction increases.

Concerning bread weight, no significant differences were observed when comparing results to the control.

Regarding specific volume, significant differences were found for all breads, when compared with the control $(1.4 \%)$. While specific volume decreased for "D'Água" (0.8\%), "Carcaça" (0.8\% and $0.0 \%)$, and "Regueifa" $(1.1 \%)$ breads, it increased for "Mistura" (1.1\% and $1.3 \%)$ bread. The results for "D'Água", "Carcaça", and "Mistura" breads are in agreement with studies that reported a volume decrease with decreasing salt concentration (McCann \& Day, 2013; Miller \& Hoseney, 2008). However, other research studies point out to a possible absence of effect on volume with a decrease in the salt concentration (Beck et al. 2012; Lynch et al., 2009). Therefore, it is difficult to establish a tendency for the impact of salt on bread volume. At some extent, technological variability, such as dough mixing time, formulation, proofing and baking time, might explain the difference in results reported.

When comparing to the control, significant higher moisture values were found for "D'Água" $(1.0 \%)$, "Carcaça" $(0.0 \%, 0.8 \%, 1.0 \%$ and $1.1 \%)$, and "Regueifa" $(0.0 \%, 1.0 \%$ and $1.1 \%)$. Results obtained are not in agreement with those reported by Lynch and co-workers (2009), where breads with salt reduction, ranging from $1.2 \%$ to $0.6 \%, 0.3 \%$ and $0 \%$ salt addition, did not present significant differences in moisture content.

Concerning chemical characteristics, i.e. salt concentration, overall, salt reduction had significant impact on salt concentration for every bread type. As it would be expected, salt concentration decreased with decreasing salt addition levels, following a linear trend for every bread type ("D'água", $\mathrm{R}^{2}=0.727, \mathrm{p}<0.001$; "Carcaça", $\mathrm{R}^{2}=0.770, \mathrm{p}<0.001$; "Mistura", $\mathrm{R}^{2}=0.808, \mathrm{p}<0.001$; "Regueifa", $\left.\mathrm{R}^{2}=0.996, \mathrm{p}<0.001\right)$

Crumb structure and colour are essential bread quality parameters along with taste and crumb texture (Skendi et al., 2010). Overall, salt addition at different concentrations had limited impact on crumb morphology, but more influence on colour parameters (Table 3). Furthermore, no linear relationship with salt addition levels was observed for any of the crumb morphology or colour parameters studied.

Regarding cell morphology, salt has been described as having a fundamental role on the formation of an even crumb (Matz, 1992). However, significant differences were only found for small size cells in "D'Água" $(0.0 \%$ and $0.80 \%)$ bread, which showed lower values than the control. The absence of significant differences on the percentage of large cells is not in agreement with what is described by Lynch and co-workers (2009), where bread without salt resulted in a smaller number of larger cells when compared to bread containing salt.

Concerning colour, salt influences Maillard reactions that occur throughou baking (Silow et al., 2016). Although salt impact is more described for bread crust, it would also be expected, at some extent, for bread crumb. Comparing to respective bread controls, salt reduction resulted in significant differences for: $\mathrm{L}^{*}$ for "D'Água"; a* for "Carcaça", "Mistura", and "Regueifa"; b* for "Carcaça"; BI for "D’Água", and "Carcaça". Control bread was lighter than $0.8 \%$ for "D'Água". While control bread was greener and yellower than $0.0 \%, 0.8 \%$, and $1.3 \%$ in "Carcaça", it was redder in "Mistura" $(1.3 \%)$, and greener in "Regueifa" $(1.0 \%)$. Moreover, "D'Água" $(0.8 \%)$ and "Carcaça" $(0.0 \%)$ breads were browner than the control. Salt reduction affected $\mathrm{L}^{*}, \mathrm{a}^{*}, \mathrm{~b}^{*}$, and BI differently and, together with the inherent influence of factors such as formulation or baking conditions on bread colour, the comparison with literature was not possible. 
Table 3 Values for physicochemical, crumb structure and colour parameters for each bread type, with different salt addition levels (\% bread).

\begin{tabular}{|c|c|c|c|c|c|c|c|c|c|c|c|c|}
\hline \multirow{2}{*}{$\begin{array}{l}\text { Bread type/ } \\
\text { Salt }(\%)\end{array}$} & \multirow[b]{2}{*}{ Weight (g) } & \multirow{2}{*}{$\begin{array}{l}\text { Specific } \\
\text { volume } \\
\left(\mathrm{cm}^{3} / \mathrm{g}\right)\end{array}$} & \multirow[b]{2}{*}{ Moisture (\%) } & \multirow{2}{*}{$\begin{array}{c}\text { Salt } \\
\text { concentration } \\
(\mathrm{g} / 100 \mathrm{~g})\end{array}$} & \multicolumn{4}{|c|}{ Cell area (\% of total cells) } & \multicolumn{4}{|c|}{ Crumb colour } \\
\hline & & & & & $\begin{array}{l}\text { Very small } \\
\text { size }\end{array}$ & Small size & Medium size & Large size & $\mathrm{L}^{*}$ & $\mathrm{a}^{*}$ & $\mathrm{~b}^{*}$ & BI \\
\hline \multicolumn{13}{|c|}{ "D’Água" } \\
\hline 0.0 & $52.23 \pm 3.91$ & $7.36 \pm 1.01$ & $35.71 \pm 0.21$ & $0.00 \pm 0.00^{* *}$ & $28.50 \pm 7.65$ & $39.27 \pm 1.53^{* *}$ & $12.69 \pm 3.79$ & $18.27 \pm 5.35$ & $61.20 \pm 2.26$ & $-2.09 \pm 0.44$ & $18.32 \pm 0.70$ & $31.61 \pm 1.59$ \\
\hline 0.8 & $52.41 \pm 3.45$ & $6.64 \pm 0.40^{*}$ & $34.98 \pm 0.24$ & $0.68 \pm 0.02^{* *}$ & $30.39 \pm 8.82$ & $40.19 \pm 3.55^{* *}$ & $12.23 \pm 3.33$ & $17.19 \pm 6.58$ & $56.99 \pm 5.59^{*}$ & $-1.49 \pm 0.42$ & $19.03 \pm 0.47$ & $37.34 \pm 3.14^{*}$ \\
\hline 1.0 & $53.89 \pm 6.65$ & $6.88 \pm 0.45$ & $40.51 \pm 5.23^{*}$ & $0.83 \pm 0.02^{* *}$ & $29.94 \pm 4.35$ & $46.62 \pm 2.09$ & $10.86 \pm 2.52$ & $12.58 \pm 3.24$ & $64.36 \pm 2.84$ & $-1.47 \pm 0.37$ & $19.01 \pm 0.99$ & $31.98 \pm 1.97$ \\
\hline 1.1 & $52.19 \pm 6.31$ & $7.36 \pm 1.01$ & $33.00 \pm 1.03$ & $0.89 \pm 0.01$ & $27.66 \pm 7.50$ & $42.44 \pm 4.46$ & $12.37 \pm 4.16$ & $17.54 \pm 7.91$ & $58.69 \pm 4.09$ & $-1.81 \pm 0.22$ & $18.00 \pm 0.31$ & $33.07 \pm 3.04$ \\
\hline 1.3 & $51.48 \pm 4.91$ & $7.00 \pm 0.50$ & $34.26 \pm 0.36$ & $1.03 \pm 0.02$ & $33.01 \pm 6.74$ & $43.80 \pm 4.01$ & $10.03 \pm 2.75$ & $13.16 \pm 4.39$ & $66.00 \pm 6.30$ & $-1.33 \pm 0.25$ & $18.74 \pm 0.37$ & $31.00 \pm 3.73$ \\
\hline 1.4 & $52.07 \pm 7.40$ & $7.67 \pm 0.88$ & $31.88 \pm 0.65$ & $1.14 \pm 0.02$ & $25.42 \pm 7.26$ & $46.07 \pm 3.92$ & $9.63 \pm 2.33$ & $17.43 \pm 6.02$ & $64.90 \pm 4.65$ & $-1.63 \pm 0.26$ & $18.57 \pm 0.49$ & $29.83 \pm 1.49$ \\
\hline \multicolumn{13}{|c|}{ "Carcaça" } \\
\hline 0.0 & $52.23 \pm 3.91$ & $3.54 \pm 0.88^{*}$ & $32.47 \pm 0.19^{*}$ & $0.00 \pm 0.00^{* *}$ & $37.12 \pm 10.18$ & $44.27 \pm 3.46$ & $8.64 \pm 4.96$ & $9.98 \pm 6.29$ & $69.58 \pm 6.40$ & $-0.94 \pm 0.28^{*}$ & $: 0.74 \pm 0.88^{*}$ & $33.30 \pm 2.92^{*}$ \\
\hline 0.8 & $52.41 \pm 3.45$ & $6.27 \pm 0.26^{*}$ & $33.46 \pm 0.29^{*}$ & $0.39 \pm 0.11$ & $32.80 \pm 6.96$ & $45.92 \pm 2.63$ & $9.31 \pm 3.27$ & $11.97 \pm 4.27$ & $72.67 \pm 3.46$ & $-1.77 \pm 0.12^{*}$ & $9.08 \pm 0.65^{*}$ & $27.53 \pm 1.23$ \\
\hline 1.0 & $53.87 \pm 6.65$ & $6.65 \pm 0.59$ & $33.01 \pm 0.17^{*}$ & $0.63 \pm 0.21$ & $26.52 \pm 5.74$ & $45.36 \pm 3.97$ & $11.84 \pm 3.22$ & $16.30 \pm 3.67$ & $68.57 \pm 4.12$ & $-1.96 \pm 0.12$ & $18.06 \pm 0.49$ & $27.37 \pm 1.55$ \\
\hline 1.1 & $52.19 \pm 6.31$ & $7.15 \pm 0.29$ & $32.71 \pm 0.22^{*}$ & $0.79 \pm 0.18$ & $27.78 \pm 9.06$ & $45.89 \pm 4.12$ & $10.93 \pm 3.87$ & $15.40 \pm 4.90$ & $68.78 \pm 5.98$ & $-1.96 \pm 0.11$ & $18.01 \pm 0.31$ & $27.33 \pm 2.70$ \\
\hline 1.3 & $51.48 \pm 4.91$ & $7.15 \pm 0.86$ & $30.66 \pm 0.26$ & $0.87 \pm 0.06$ & $33.76 \pm 9.06$ & $47.10 \pm 3.11$ & $9.11 \pm 2.69$ & $10.03 \pm 4.98$ & $72.90 \pm 5.86$ & $-1.67 \pm 0.17^{*}$ & $.9 .08 \pm 0.48^{*}$ & $26.47 \pm 0.75$ \\
\hline 1.4 & $52.07 \pm 7.40$ & $7.24 \pm 0.56$ & $31.22 \pm 0.37$ & $0.87 \pm 0.19$ & $37.19 \pm 9.06$ & $45.95 \pm 3.74$ & $6.91 \pm 1.70$ & $9.96 \pm 5.64$ & $74.04 \pm 4.40$ & $-2.05 \pm 0.15$ & $18.04 \pm 0.42$ & $25.26 \pm 2.38$ \\
\hline 0.0 & $52.41 \pm 5.44$ & $4.68 \pm 0.23$ & $28.99 \pm 1.58$ & $0.00 \pm 0.00^{* *}$ & $35.95 \pm 7.79$ & $43.78 \pm 5.63$ & $8.31 \pm 2.00$ & $11.96 \pm 4.21$ & $53.71 \pm 2.47$ & $1.50 \pm 0.07$ & $20.45 \pm 0.56$ & $47.89 \pm 3.02$ \\
\hline 0.8 & $52.05 \pm 0.35$ & $5.07 \pm 0.23$ & $32.35 \pm 0.2$ & $0.49 \pm 0.07$ & $34.27 \pm 11.05$ & $45.51 \pm 5.50$ & $8.48 \pm 2.07$ & $9.69 \pm 2.49$ & $54.13 \pm 4.79$ & $1.50 \pm 0.25$ & $20.38 \pm 0.63$ & $47.81 \pm 3.64$ \\
\hline 1.0 & $53.00 \pm 4.88$ & $5.27 \pm 0.40$ & $31.81 \pm 0.36$ & $0.50 \pm 0.17$ & $38.16 \pm 10.70$ & $41.04 \pm 8.21$ & $8.77 \pm 4.52$ & $12.03 \pm 5.80$ & $52.29 \pm 4.87$ & $1.59 \pm 0.13$ & $20.47 \pm 0.48$ & $50.44 \pm 4.58$ \\
\hline 1.1 & $50.94 \pm 7.99$ & $5.56 \pm 0.40^{*}$ & $31.31 \pm 0.43$ & $0.76 \pm 0.12$ & $33.04 \pm 11.03$ & $42.13 \pm 4.94$ & $9.55 \pm 2.83$ & $15.28 \pm 7.04$ & $51.38 \pm 4.41$ & $1.59 \pm 0.20$ & $20.02 \pm 0.69$ & $50.02 \pm 3.25$ \\
\hline 1.3 & $51.80 \pm 4.38$ & $6.14 \pm 0.34^{*}$ & $30.79 \pm 0.57$ & $0.83 \pm 0.21$ & $36.22 \pm 5.55$ & $38.48 \pm 6.04$ & $8.78 \pm 3.74$ & $13.58 \pm 2.82$ & $48.49 \pm 3.10$ & $1.11 \pm 0.19^{*}$ & $19.35 \pm 0.42$ & $50.80 \pm 3.55$ \\
\hline 1.4 & $52.70 \pm 4.76$ & $4.91 \pm 0.60$ & $30.34 \pm 0.35$ & $0.78 \pm 0.21$ & $31.09 \pm 7.42$ & $46.54 \pm 3.26$ & $10.11 \pm 2.67$ & $13.63 \pm 2.73$ & $53.17 \pm 4.12$ & $1.58 \pm 0.12$ & $19.87 \pm 0.57$ & $46.93 \pm 2.48$ \\
\hline \multicolumn{13}{|c|}{ "Regueifa" } \\
\hline 0.0 & $408.00 \pm 25.73$ & $4.69 \pm 0.34$ & $35.08 \pm 0.57^{*}$ & $0.00 \pm 0.00^{* *}$ & $34.94 \pm 12.75$ & $50.41 \pm 6.45$ & $6.50 \pm 1.20$ & $3.75 \pm 0.89$ & $88.69 \pm 4.40$ & $-2.85 \pm 0.16$ & $19.41 \pm 0.52$ & $21.47 \pm 1.88$ \\
\hline 0.8 & $435.50 \pm 35.23$ & $4.91 \pm 0.40$ & $33.59 \pm 0.29$ & $0.34 \pm 0.13^{* *}$ & $32.52 \pm 9.40$ & $50.45 \pm 3.07$ & $9.66 \pm 3.73$ & $7.37 \pm 4.84$ & $89.63 \pm 2.97$ & $-2.69 \pm 0.19$ & $18.83 \pm 0.36$ & $20.50 \pm 0.94$ \\
\hline 1.0 & $431.25 \pm 26.26$ & $4.84 \pm 0.12$ & $34.54 \pm 0.16^{*}$ & $0.44 \pm 0.02$ & $27.33 \pm 8.41$ & $49.31 \pm 3.70$ & $11.16 \pm 3.20$ & $12.21 \pm 8.02$ & $85.15 \pm 3.75$ & $-2.60 \pm 0.11^{*}$ & $19.86 \pm 0.22$ & $23.35 \pm 1.50$ \\
\hline 1.1 & $458.75 \pm 33.26$ & $4.28 \pm 0.23^{*}$ & $35.68 \pm 0.13^{*}$ & $0.54 \pm 0.07$ & $34.57 \pm 4.18$ & $50.82 \pm 6.15$ & $7.41 \pm 1.45$ & $5.35 \pm 1.50$ & $89.14 \pm 5.20$ & $-2.62 \pm 0.19$ & $20.10 \pm 0.88$ & $22.46 \pm 1.14$ \\
\hline 1.3 & $415.00 \pm 32.40$ & $4.62 \pm 0.31$ & $33.70 \pm 0.36$ & $1.01 \pm 0.21$ & $29.55 \pm 7.31$ & $49.79 \pm 2.48$ & $9.52 \pm 3.29$ & $9.15 \pm 2.99$ & $82.66 \pm 12.98$ & $-2.69 \pm 0.13$ & $20.02 \pm 1.01$ & $24.93 \pm 4.61$ \\
\hline 1.4 & $422.50 \pm 44.44$ & $4.84 \pm 0.14$ & $33.60 \pm 0.23$ & $1.18 \pm 0.29$ & $29.91 \pm 6.75$ & $52.50 \pm 5.92$ & $8.82 \pm 4.36$ & $8.77 \pm 4.65$ & $87.35 \pm 4.64$ & $-2.87 \pm 0.18$ & $19.75 \pm 0.49$ & $22.33 \pm 1.90$ \\
\hline
\end{tabular}

Data expressed as mean \pm standard ( $\mathrm{n}=10$, for physicochemical parameters; $\mathrm{n}=36$, for crumb structure and colour parameters).

BI, Browning index; Large size, Cell area $>10.0\left(\mathrm{~mm}^{2}\right)$; Medium size, $3.0<$ Cell area $\leq 10.0\left(\mathrm{~mm}^{2}\right)$; ns, not significant; Small size, $0.2<$ Cell area $\leq 3.0\left(\mathrm{~mm}^{2}\right)$; Very small size, Cell area $\leq 0.2(\mathrm{~mm})^{2}$. Bold values show statistically significant differences $(\mathrm{p}<0.05)$ in each bread for a given parameter when compared with the control $(1.4 \%)$

"Means were compared by Dunnett's test.

Medians were compared by Dunn's test. 
Table 4 Values for sensory analysis scores for each bread type, with different salt addition levels (\% bread).

\begin{tabular}{|c|c|c|c|c|c|c|c|c|c|c|c|c|c|c|c|c|c|}
\hline \multirow{2}{*}{$\begin{array}{l}\text { Bread type/ } \\
\text { Salt (\%) }\end{array}$} & \multicolumn{6}{|c|}{ Appearance } & \multicolumn{3}{|l|}{ Odour } & \multicolumn{3}{|l|}{ Texture } & \multicolumn{4}{|c|}{ Aroma } & \multirow[t]{2}{*}{$\begin{array}{c}\begin{array}{c}\text { Overall } \\
\text { assessment }\end{array} \\
\text { a }\end{array}$} \\
\hline & $\begin{array}{c}\begin{array}{c}\text { Crust color } \\
\text { intensity }\end{array} \\
\end{array}$ & $\begin{array}{c}\text { Crumb color } \\
\text { intensity }\end{array}$ & $\begin{array}{c}\text { Number of large } \\
\text { cells }\end{array}$ & $\begin{array}{c}\text { Number of small } \\
\text { cells }\end{array}$ & Cell circularity & $\begin{array}{c}\begin{array}{c}\text { Cell } \\
\text { homogeneity }\end{array} \\
\end{array}$ & Odour intensity & Crunchy crust & Cohesiveness & Adhesiveness & Crumb elasticity & Shape recovery & Salty & Sweet & Bread aroma & Aftertaste & \\
\hline 0.0 & $4.0(2.0-5.0)$ & $3.0(2.0-3.0)$ & $6.0(1.0-7.0)$ & $4.0(2.0-7.0)$ & $3.0(2.0-5.0)$ & $3.0(1.0-5.0)$ & $4.0(3.0-6.0)$ & $2.0(1.0-5.0)$ & $4.0(2.0-5.0)$ & $2.0(2.0-4.0)$ & $3.0(2.0-7.0)$ & $6.0(5.0-6.0)$ & $2.0^{*}(1.0-4.0)$ & $2.0(1.0-3.0)$ & $4.5^{*}(2.0-5.0)$ & $4.0(2.0-5.0)$ & $4.0^{*}(1.0-6.0)$ \\
\hline 0.8 & $4.0(3.0-6.0)$ & $3.0(2.0-4.0)$ & $5.0(1.0-6.0)$ & $4.0(2.0-7.0)$ & $3.0(3.0-5.0)$ & $3.0(2.0-6.0)$ & $4.0(3.0-6.0)$ & $2.0(2.0-5.0)$ & $4.0^{*}(2.0-4.0)$ & $2.0(2.0-4.0)$ & $3.0(2.0-6.0)$ & $6.0(4.0-7.0)$ & $3.0^{*}(2.0-4.0)$ & $2.0(1.0-2.0)$ & $5.0(4.0-5.0)$ & $4.0(2.0-6.0)$ & $5.0(4.0-6.0)$ \\
\hline 1.0 & $4.0(3.0-6.0)$ & $3.0(2.0-4.0)$ & $5.0(3.0-7.0)$ & $4.0(4.0-6.0)$ & $3.0(2.0-4.0)$ & $2.0(1.0-4.0)$ & $4.0(3.0-6.0)$ & $2.0(1.0-5.0)$ & $4.0(2.0-5.0)$ & $2.0(2.0-4.0)$ & $3.0(2.0-6.0)$ & $6.0(4.0-7.0)$ & $3.0^{*}(2.0-4.0)$ & $2.0(1.0-3.0)$ & $5.0(2.0-5.0)$ & $4.0(3.0-5.0)$ & $5.0(3.0-6.0)$ \\
\hline 1.1 & $4.0(3.0-5.0)$ & $3.0(2.0-3.0)$ & $6.0(2.0-7.0)$ & $4.0(2.0-6.0)$ & $3.0(2.0-5.0)$ & $2.0(1.0-5.0)$ & $4.0(2.0-5.0)$ & $2.0(2.0-4.0)$ & $4.0(2.0-5.0)$ & $2.0(2.0-3.0)$ & $3.0(2.0-6.0)$ & $6.0(3.0-7.0)$ & $4.0(3.0-5.0)$ & $2.0(1.0-3.0)$ & $5.0(4.0-5.0)$ & $4.0(3.0-4.0)$ & $5.0(4.0-6.0)$ \\
\hline 1.3 & $4.0(2.0-5.0)$ & $3.0(2.0-3.0)$ & $5.5(2.0-6.0)$ & $4.0(3.0-7.0)$ & $3.0(2.0-5.0)$ & $2.5(2.0-5.0)$ & $4.0(3.0-5.0)$ & $2.0(1.0-4.0)$ & $4.0(3.0-5.0)$ & $2.0(2.0-4.0)$ & $3.0(2.0-6.0)$ & $6.0(4.0-7.0)$ & $4.0(1.0-5.0)$ & $2.0(1.0-5.0)$ & $5.0(2.0-5.0)$ & $4.0(3.0-5.0)$ & $5.0(1.0-7.0)$ \\
\hline 1.4 & $4.0(2.0-6.0)$ & $3.0(2.0-3.0)$ & $6.0(2.0-7.0)$ & $4.0(3.0-6.0)$ & $3.0(2.0-6.0)$ & $2.0(1.0-5.0)$ & $5.0(2.0-6.0)$ & $3.0(1.0-5.0)$ & $4.0(2.0-5.0)$ & $2.0(2.0-3.0)$ & $3.0(2.0-5.0)$ & $6.0(5.0-6.0)$ & $3.0(3.0-6.0)$ & $2.0(1.0-3.0)$ & $5.0(4.0-5.0)$ & $4.0(3.0-5.0)$ & $5.0(4.0-7.0)$ \\
\hline 0.0 & $3.0(2.0-4.0)$ & $2.0(2.0-4.0)$ & $2.0(1.0-4.0)$ & $6.0(4.0-6.0)$ & $4.0(3.0-6.0)$ & $4.0(3.0-7.0)$ & $5.0(3.0-7.0)$ & $2.0(1.0-5.0)$ & $3.0(2.0-4.0)$ & $2.0(2.0-4.0)$ & $3.0(1.0-4.0)$ & $6.0(4.0-6.0)$ & $2.0^{*}(1.0-6.0)$ & $2.0(1.0-3.0)$ & $4.0(1.0-6.0)$ & $5.0(3.0-6.0)$ & $3.5(1.0-5.0)$ \\
\hline 0.8 & $3.0(2.0-5.0)$ & $2.0(2.0-3.0)$ & $2.0(1.0-3.0)$ & $6.0(5.0-6.0)$ & $4.0(3.0-6.0)$ & $4.0(1.0-6.0)$ & $5.0(3.0-6.0)$ & $3.0(1.0-5.0)$ & $3.0(2.0-4.0)$ & $2.0(2.0-5.0)$ & $3.0(2.0-4.0)$ & $6.0(4.0-6.0)$ & $4.0(2.0-5.0)$ & $2.0(1.0-3.0)$ & $5.0(3.0-5.0)$ & $5.0(3.0-6.0)$ & $5.0(3.0-6.0)$ \\
\hline 1.0 & $3.0(1.0-4.0)$ & $2.0(1.0-2.0)$ & $2.0(1.0-4.0)$ & $6.0(5.0-6.0)$ & $4.0(3.0-6.0)$ & $4.0(2.0-6.0)$ & $5.0(4.0-7.0)$ & $3.0(1.0-5.0)$ & $3.0(2.0-5.0)$ & $2.0(2.0-4.0)$ & $3.0(2.0-5.0)$ & $6.0(4.0-6.0)$ & $4.0(2.0-5.0)$ & $2.0(1.0-2.0)$ & $5.0(4.0-6.0)$ & $5.0(4.0-7.0)$ & $5.0(3.0-5.0)$ \\
\hline 1.1 & $3.0(2.0-4.0)$ & $2.0(1.0-2.0)$ & $2.0(1.0-4.0)$ & $6.0(6.0-6.0)$ & $4.0(3.0-6.0)$ & $4.0(3.0-6.0)$ & $5.0(4.0-6.0)$ & $2.0(1.0-5.0)$ & $3.0(2.0-5.0)$ & $2.0(2.0-3.0)$ & $3.0(2.0-5.0)$ & $6.0(4.0-6.0)$ & $4.0(3.0-6.0)$ & $2.0(1.0-3.0)$ & $5.0(4.0-5.0)$ & $5.0(4.0-5.0)$ & $5.0^{*}(5.0-6.0)$ \\
\hline 1.3 & $3.0(2.0-6.0)$ & $2.0(1.0-2.0)$ & $2.0(1.0-4.0)$ & $6.0(5.0-6.0)$ & $4.0(3.0-6.0)$ & $4.0(2.0-6.0)$ & $5.0(3.0-6.0)$ & $2.0(1.0-4.0)$ & $3.0(2.0-4.0)$ & $2.0(2.0-5.0)$ & $3.0(2.0-4.0)$ & $6.0(4.0-6.0)$ & $4.0(3.0-5.0)$ & $2.0(1.0-3.0)$ & $5.0(4.0-6.0)$ & $5.0(4.0-6.0)$ & $5.0(4.0-6.0)$ \\
\hline 1.4 & $3.0(2.0-4.0)$ & $2.0(2.0-2.0)$ & $2.0(1.0-5.0)$ & $6.0(5.0-5.0)$ & $4.0(3.0-5.0)$ & $4.0(3.0-6.0)$ & $5.0(3.0-6.0)$ & $2.0(1.0-4.0)$ & $3.0(2.0-4.0)$ & $2.0(2.0-5.0)$ & $3.0(2.0-4.0)$ & $6.0(4.0-6.0)$ & $4.0(1.0-6.0)$ & $2.0(1.0-5.0)$ & $5.0(3.0-6.0)$ & $5.0(4.0-6.0)$ & $4.0(2.0-6.0)$ \\
\hline 0.0 & $6.0(3.0-7.0)$ & $5.0(3.0-6.0)$ & $4.0(2.0-5.0)$ & $5.0(4.0-6.0)$ & $4.0(1.0-5.0)$ & $3.0(2.0-6.0)$ & $4.0(3.0-6.0)$ & $4.0(2.0-6.0)$ & $4.0(3.0-5.0)$ & $2.0(2.0-4.0)$ & $3.0(2.0-5.0)$ & $6.0(4.0-7.0)$ & $2.0^{*}(1.0-3.0)$ & $1.0^{*}(1.0-3.0)$ & $3.5^{*}(2.0-4.0)$ & $4.0(2.0-5.0)$ & $4.0^{*}(2.0-6.0)$ \\
\hline 0.8 & $6.0(3.0-7.0)$ & $5.0(2.0-6.0)$ & $4.0(2.0-5.0)$ & $5.0(4.0-6.0)$ & $4.0(2.0-6.0)$ & $3.0(2.0-5.0)$ & $4.0(3.0-5.0)$ & $3.0(2.0-5.0)$ & $4.0(3.0-6.0)$ & $2.0(2.0-5.0)$ & $3.0(2.0-6.0)$ & $6.0(5.0-7.0)$ & $3.0^{*}(2.0-4.0)$ & $2.0(1.0-3.0)$ & $4.0(2.0-4.0)$ & $4.0(3.0-5.0)$ & $5.0(4.0-6.0)$ \\
\hline 1.0 & $6.0(4.0-7.0)$ & $5.0(3.0-5.0)$ & $4.0(2.0-6.0)$ & $5.0(4.0-6.0)$ & $4.0(2.0-5.0)$ & $3.0(2.0-5.0)$ & $4.0(2.0-6.0)$ & $3.0(2.0-6.0)$ & $4.0(3.0-5.0)$ & $2.0(2.0-3.0)$ & $3.0(2.0-6.0)$ & $6.0(4.0-6.0)$ & $4.0(3.0-5.0)$ & $2.0(1.0-3.0)$ & $4.0(2.0-6.0)$ & $4.0(3.0-5.0)$ & $5.0(3.0-7.0)$ \\
\hline 1.1 & $6.0(3.0-6.0)$ & $5.0(2.0-2.0)$ & $4.0(2.0-4.0)$ & $5.0(3.0-6.0)$ & $4.0(2.0-5.0)$ & $3.0(2.0-4.0)$ & $4.0(3.0-6.0)$ & $3.0(2.0-5.0)$ & $4.0(3.0-5.0)$ & $2.0(2.0-3.0)$ & $3.0(2.0-5.0)$ & $6.0(4.0-6.0)$ & $4.0(3.0-5.0)$ & $2.0(1.0-3.0)$ & $4.0(3.0-5.0)$ & $4.0(3.0-5.0)$ & $5.0(4.0-6.0)$ \\
\hline 1.3 & $6.0(3.0-7.0)$ & $5.0(2.0-6.0)$ & $4.0(3.0-6.0)$ & $5.0(2.0-6.0)$ & $4.0(3.0-5.0)$ & $3.0(2.0-4.0)$ & $4.0(3.0-6.0)$ & $4.0(2.0-5.0)$ & $4.0(2.0-5.0)$ & $2.0(2.0-3.0)$ & $3.0(2.0-6.0)$ & $6.0(3.0-6.0)$ & $4.0(3.0-5.0)$ & $2.0(1.0-3.0)$ & $4.0(4.0-5.0)$ & $4.0(3.0-5.0)$ & $5.0(4.0-6.0)$ \\
\hline 1.4 & $6.0(4.0-7.0)$ & $5.0(2.0-5.0)$ & $4.0(2.0-5.0)$ & $5.0(4.0-6.0)$ & $4.0(2.0-6.0)$ & $3.0(2.0-5.0)$ & $4.0(3.0-6.0)$ & $3.0(2.0-4.0)$ & $4.0(3.0-5.0)$ & $2.0(2.0-3.0)$ & $3.0(2.0-6.0)$ & $6.0(4.0-6.0)$ & $4.0(3.0-6.0)$ & $2.0(1.0-3.0)$ & $4.0(4.0-5.0)$ & $4.0(3.0-5.0)$ & $5.0(4.0-6.0)$ \\
\hline 0.0 & $4.0(2.0-6.0)$ & $1.0(1.0-1)$ & $2.0(1-2)$ & $5.0(4.0-7.0)$ & $3.0(2.0-6.0)$ & $4.0(2.0-7.0)$ & $4.5(2.0-6.0)$ & $4.0(2.0-5.0)$ & $6.0(2.0-7.0)$ & $5.0(1.0-7.0)$ & $5.0(3.0-5.0)$ & $3.0(1.0-5.0)$ & $1.0^{*}(1.0-2.0)$ & $2.0(1.0-5.0)$ & $3.0^{*}(2.0-5.0)$ & $3.0(1.0-4.0)$ & $3.0^{*}(2.0-6.0)$ \\
\hline 0.8 & $4.0(2.0-5.0)$ & $1.0(1.0-2)$ & $1.5(1-2)$ & $6.0(5.0-7.0)$ & $3.0(1.0-6.0)$ & $5.0(4.0-7.0)$ & $4.0(2.0-6.0)$ & $3.0(1.0-5.0)$ & $6.0(2.0-7.0)$ & $5.0(1.0-6.0)$ & $5.0(2.0-6.0)$ & $3.0(1.0-5.0)$ & $3.0^{*}(2.0-4.0)$ & $2.0(1.0-6.0)$ & $4.0(2.0-6.0)$ & $2.0(2.0-5.0)$ & $6.0(4.0-7.0)$ \\
\hline 1.0 & $4.0(2.0-6.0)$ & $1.0(1.0-2)$ & $2.0(2-3)$ & $5.0(4.0-7.0)$ & $2.0(2.0-5.0)$ & $4.0(2.0-5.0)$ & $4.0(3.0-6.0)$ & $3.0(1.0-5.0)$ & $6.0(4.0-7.0)$ & $5.0(3.0-6.0)$ & $5.0(3.0-5.0)$ & $3.0(2.0-5.0)$ & $3.0(2.0-4.0)$ & $3.0(1.0-5.0)$ & $4.0(3.0-5.0)$ & $2.0(2.0-4.0)$ & $6.0(4.0-6.0)$ \\
\hline 1.1 & $4.0(1.0-5.0)$ & $1.0(1.0-2)$ & $2.0(1-2)$ & $5.0(4.0-7.0)$ & $2.0(1.0-5.0)$ & $4.0(3.0-7.0)$ & $4.0(3.0-6.0)$ & $3.0(1.0-5.0)$ & $6.0(2.0-7.0)$ & $5.0(2.0-5.0)$ & $5.0(2.0-5.0)$ & $3.0(2.0-6.0)$ & $3.0(2.0-5.0)$ & $3.0(2.0-5.0)$ & $4.0(3.0-5.0)$ & $2.0(2.0-4.0)$ & $6.0(5.0-7.0)$ \\
\hline 1.3 & $4.0(3.0-6.0)$ & $1.0(1.0-2)$ & $2.0(1-3)$ & $5.0(4.0-7.0)$ & $2.0(2.0-6.0)$ & $4.0(2.0-6.0)$ & $4.0(2.0-6.0)$ & $3.0(2.0-5.0)$ & $6.0(3.0-6.0)$ & $5.0(3.0-6.0)$ & $5.0(3.0-7.0)$ & $4.0(2.0-5.0)$ & $3.0(2.0-5.0)$ & $4.0(2.0-5.0)$ & $4.0(4.0-5.0)$ & $3.0(2.0-4.0)$ & $6.0(5.0-7.0)$ \\
\hline 1.4 & $4.0(2.0-6.0)$ & $1.0(1.0-1)$ & $2.0(1-2)$ & $5.0(4.0-7.0)$ & $2.5(1.5-6.0)$ & $4.0(4.0-7.0)$ & $4.0(2.0-6.0)$ & $3.0(1.0-5.0)$ & $6.0(3.0-6.0)$ & $5.0(3.0-6.0)$ & $5.0(2.0-6.0)$ & $3.0(2.0-5.0)$ & $4.0(2.0-6.0)$ & $3.0(2.0-5.0)$ & $4.0(3.0-5.0)$ & $2.5(2.0-5.0)$ & $6.0(2.0-6.0)$ \\
\hline
\end{tabular}

Data expressed as median (minimum-maximum), $(\mathrm{n}=24)$.

Bold values show statistically significant differences $(\mathrm{p}<0.05)$ in each bread for a given parameter when compared with the control $(1.4 \%)$

Bold values show statistically significant
"Medians were compared by Dunn's test. 


\section{Bread sensory analysis}

\section{Descriptive Sensory Analysis}

Studies (Antúnez et al., 2016; Lynch et al., 2009; Rødbotten et al., 2015) have shown that salt reduction has a negative impact on bread characteristics, which can potentially affect its sensory characteristics and, consequently on consumer's preferences.

Values for sensory analysis scores for each bread type with different salt levels are presented in Table 4. Overall, comparing to control (1.4\%), salt reduction had limited impact on sensory evaluation of the different bread types. Considering appearance attributes, significant differences were only found for number of large cells in "Mistura" and cell homogeneity in "D'Água". For "Mistura", the control had more large cells the $1.1 \%$, whereas for "D'Água" cells distribution was less homogenous in control than for $0.0 \%$ and $0.8 \%$. As for odour attribute, no significant differences were observed. With texture attributes, significan differences were detected for crunchy crust in "Carcaça" and "Mistura", and cohesiveness in "D'Água". Control bread was less crunchy than $0.8 \%$ and $1.0 \%$ in "Carcaça", and $0.0 \%$ and $1.3 \%$ in "Mistura". Although with the same median values, the mean of ranking of cohesiveness was significantly higher for contro than for $0.8 \%$ in "D'Água", therefore control was more cohesive than $0.8 \%$. Aroma attributes was the category where salt reduction had more impact, with significant differences found for salty in all bread types, sweet in "Mistura", and bread aroma in "D'Água", in "Mistura", and in "Regueifa". Though control bread was perceived as saltier than: $0.0 \%$ for all breads, $0.8 \%$ for all breads, except "Carcaça", and $1.0 \%$ for "D'Água"; it was sweeter than $0.0 \%$ in "Mistura". Moreover, control breads had more bread aroma than $0.0 \%$, except for "Carcaça". Finally, for overall assessment, significant differences were found for all bread types. Breads without salt addition $(0.0 \%)$ were less preferable than control in "D'Água", "Mistura", and Regueifa", while this was observed with $1.1 \%$ for "Carcaça".
Globally, the effect of salt reduction was not consistent across sensory characteristics evaluated by the trained panel, which makes comparison with literature difficult and meaningless.

When sensory profile was compared with image analysis, the sensory panel was not able to identify differences between control and breads with salt reduction for some parameters, including cell distribution as a function of their area and crumb colour. Thus, data gathered from image analysis provided relevant information that would not be possible to obtain from sensory data.

\section{Consumer test}

Consumer hedonic perception of salt reduced products is relevant. While the ability to identify differences among samples by trained assessors outperform consumers, they may be too conservative (Ishii et al., 2007). Thresholds estimated with trained assessors are based on differences that may not be relevant for consumers' liking preferences.

The results obtained from the consumer test are shown in Table 5. Comparing to respective control bread $(1.4 \%)$, differences were evident. Apart from "Regueifa", $0.0 \%$ breads were the only ones with significant lower scores. The lack of salt addition had a negative effect on the overall liking, for "D'água", "Carcaça", and "Mistura". This negative effect was also observable for other liking attributes, such as appearance liking and texture liking for "Carcaça", and taste liking for both "Carcaça" and "Mistura". Overall, from consumer's point of view, only the lack of salt addition was relevant, which was more noticeable for "Carcaç" and less evident for "Regueifa". This results are promising, comparing to what is described by other authors. Rødbotten and co-workers (2015) reported that bread sodium content reduction had a negative impact on consumer preference from five European countries, even when they were moderately positive towards a salt reduction on bread. Antúnez and co-workers (2016) suggested that bread salt content could be reduced by $10 \%$ without affecting consumer sensory perception.

Table 5 Overall liking attribute values from consumer acceptance testing for each bread type, with different salt addition levels $(\%$ bread) (n consumers $=80)$

\begin{tabular}{|c|c|c|c|c|c|}
\hline $\begin{array}{l}\text { Bread type/ } \\
\text { Salt }(\%)\end{array}$ & Appearance liking & Aroma liking & Taste liking & Texture liking & Overall liking \\
\hline \multicolumn{6}{|c|}{ "D’Água" (n=20) } \\
\hline 0.0 & $5.0(2.0-7.0)$ & $4.0(1.0-6.0)$ & $2.0(1.0-6.0)$ & $4.0(1.0-7.0)$ & $3.0^{*}(1.0-6.0)$ \\
\hline 0.8 & $5.0(2.0-7.0)$ & $5.0(2.0-7.0)$ & $4.5(2.0-7.0)$ & $5.0(2.0-7.0)$ & $5.0(2.0-7.0)$ \\
\hline 1.0 & $5.0(2.0-7.0)$ & $5.0(2.0-6.0)$ & $4.5(1.0-7.0)$ & $4.5(1.0-7.0)$ & $5.0(2.0-7.0)$ \\
\hline 1.1 & $5.0(2.0-7.0)$ & $4.5(3.0-6.0)$ & $5.0(2.0-6.0)$ & $5.0(4.0-7.0)$ & $5.0(3.0-6.0)$ \\
\hline 1.3 & $5.0(2.0-6.0)$ & $4.5(2.0-6.0)$ & $5.0(2.0-7.0)$ & $5.5(2.0-7.0)$ & $5.0(2.0-6.0)$ \\
\hline 1.4 & $5.0(2.0-7.0)$ & $4.5(1.0-6.0)$ & $4.0(1.0-7.0)$ & $5.0(1.0-7.0)$ & $5.0(1.0-7.0)$ \\
\hline \multicolumn{6}{|c|}{ Carcaça" (n=20) } \\
\hline 0.0 & $4.5^{*}(1.0-7.0)$ & $4.0(2.0-6.0)$ & $3.0^{*}(1.0-6.0)$ & $3.0^{*}(1.0-6.0)$ & $3.0^{*}(1.0-7.0)$ \\
\hline 0.8 & $5.5(2.0-7.0)$ & $5.0(3.0-7.0)$ & $5.0(1.0-7.0)$ & $5.0(3.0-7.0)$ & $5.0(3.0-7.0)$ \\
\hline 1.0 & $5.5(2.0-7.0)$ & $5.0(3.0-7.0)$ & $5.0(2.0-7.0)$ & $5.0(3.0-7.0)$ & $5.0(3.0-7.0)$ \\
\hline 1.1 & $6.0(2.0-7.0)$ & $5.0(3.0-6.0)$ & $5.5(3.0-7.0)$ & $5.0(2.0-6.0)$ & $5.0(2.0-6.0)$ \\
\hline 1.3 & $6.0(3.0-7.0)$ & $5.0(1.0-7.0)$ & $5.0(1.0-7.0)$ & $4.0(1.0-7.0)$ & $5.0(1.0-7.0)$ \\
\hline 1.4 & $6.0(4.0-7.0)$ & $5.5(2.0-7.0)$ & $5.0(1.0-7.0)$ & $6.0(1.0-7.0)$ & $5.5(3.0-7.0)$ \\
\hline \multicolumn{6}{|c|}{ 'Mistura" (n=20) } \\
\hline 0.0 & $5.0(2.0-7.0)$ & $5.0(2.0-6.0)$ & $3.0^{*}(2.0-5.0)$ & $4.5(2.0-7.0)$ & $4.0^{*}(2.0-6.0)$ \\
\hline 0.8 & $6.0(4.0-7.0)$ & $6.0(4.0-7.0)$ & $6.0(5.0-7.0)$ & $6.0(3.0-7.0)$ & $6.0(4.0-7.0)$ \\
\hline 1.0 & $6.0(4.0-7.0)$ & $6.0(4.0-7.0)$ & $5.5(3.0-7.0)$ & $6.0(3.0-7.0)$ & $5.5(4.0-7.0)$ \\
\hline 1.1 & $6.0(4.0-7.0)$ & $6.0(4.0-7.0)$ & $6.0(3.0-7.0)$ & $6.0(3.0-7.0)$ & $6.0(4.0-7.0)$ \\
\hline 1.3 & $6.0(2.0-7.0)$ & $6.0(4.0-7.0)$ & $6.0(4.0-7.0)$ & $5.5(3.0-7.0)$ & $5.5(4.0-7.0)$ \\
\hline 1.4 & $6.0(4.0-7.0)$ & $5.0(4.0-7.0)$ & $6.0(4.0-7.0)$ & $6.0(3.0-7.0)$ & $6.0(4.0-7.0)$ \\
\hline \multicolumn{6}{|c|}{ 'Regueifa" $(n=20)$} \\
\hline 0.0 & $6.0(3.0-7.0)$ & $5.0(2.0-7.0)$ & $3.0(1.0-6.0)$ & $5.0(2.0-7.0)$ & $4.0(2.0-6.0)$ \\
\hline 0.8 & $5.0(4.0-6.0)$ & $5.0(3.0-7.0)$ & $6.0(3.0-7.0)$ & $6.0(4.0-7.0)$ & $6.0(4.0-6.0)$ \\
\hline 1.0 & $5.5(3.0-7.0)$ & $5.0(3.0-7.0)$ & $5.5(4.0-7.0)$ & $5.0(3.0-7.0)$ & $5.0(3.0-7.0)$ \\
\hline 1.1 & $5.5(3.0-7.0)$ & $5.5(3.0-7.0)$ & $5.5(2.0-7.0)$ & $5.5(3.0-7.0)$ & $5.0(3.0-7.0)$ \\
\hline 1.3 & $5.5(3.0-7.0)$ & $5.0(4.0-7.0)$ & $5.0(2.0-7.0)$ & $6.0(3.0-7.0)$ & $6.0(4.0-7.0)$ \\
\hline 1.4 & $6.0(3.0-7.0)$ & $5.0(3.0-7.0)$ & $4.5(2.0-7.0)$ & $5.0(2.0-6.0)$ & $5.0(3.0-6.0)$ \\
\hline
\end{tabular}

Data expressed as median (minimum-maximum), $(\mathrm{n}=80)$.

Bold values show statistically significant differences $(\mathrm{p}<0.05)$ in each bread for a given parameter when compared with the control $(1.4 \%)$

Means were compared by Dunnett's test.

*** Medians were compared by Dunn's test.

\section{External Preference Mapping}

For each bread type, the resulting preference map (see Figure 1) shows the best fitting model for each cluster and consumers preference.

For "D'Água" bread (A) (Figure 1a), the vector model was the best fit for cluster $1(\mathrm{C} 1)$ and cluster $(3)$ but only significant $(\mathrm{p}=0.097)$ for $\mathrm{C} 1$, while elliptical model was the best $(\mathrm{p}=0.094)$ for clusters $2(\mathrm{C} 2)$. In $\mathrm{C} 1$ and $\mathrm{C} 3$, the vector indicated the direction in the map where overall acceptability increased. In $\mathrm{C} 1$, the preference order was $\mathrm{A} 1.4>\mathrm{A} 0.8>\mathrm{A} 1.3>\mathrm{A} 1.0>\mathrm{A} 1.1>\mathrm{A} 0.0$, while in $\mathrm{C} 3$ was $\mathrm{A} 1.4>\mathrm{A} 1.1>\mathrm{A} 1.3>\mathrm{A} 1.0>\mathrm{A} 0.8>\mathrm{A} 0.0$. The elliptical model for $\mathrm{C} 2$ showed a saddle point, where the thicker lines indicated the direction in which overall acceptability increased, and the thinner ones to the direction in which it decreased. Here, the preference order was A1.1 > A0.8> A1.0>A1.3> A1.4> A0.0. 
Table 6 Results of PLS regression between bread analytical parameters (X-variables) and sensory attributes (Y-variables) for all bread formulations.

\begin{tabular}{|c|c|c|c|c|c|}
\hline Sensory attributes & $\mathbf{Q}^{2}$ & $\mathbf{R}^{2} \mathbf{Y}$ & $\mathbf{R}^{2} \mathbf{X}$ & RSME & Latent variables $^{1}$ \\
\hline \multicolumn{6}{|l|}{ Appearance } \\
\hline Crust colour intensity & 0.836 & 0.929 & 0.808 & 0.225 & 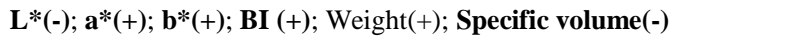 \\
\hline Crumb colour intensity & 0.925 & 0.986 & 0.862 & 0.097 & Circularity (+); $\mathbf{L}^{*}(-) ; \mathbf{a}^{*}(+) ; \mathbf{B I}(+)$ \\
\hline Number of large cells & 0.415 & 0.579 & 0.406 & 0.597 & - \\
\hline Number of small cells & 0.114 & 0.676 & 0.568 & 0.547 & - \\
\hline Cell circularity & 0.465 & 0.593 & 0.332 & 0.558 & - \\
\hline Cell homogeneity & -0.451 & 0.841 & 0.601 & 0.314 & - \\
\hline \multicolumn{6}{|l|}{ Odour } \\
\hline Odour intensity & 0.296 & 0.888 & 0.531 & 0.353 & - \\
\hline \multicolumn{6}{|l|}{ Texture } \\
\hline Crunchy crust & 0.212 & 0.773 & 0.121 & 0.441 & - \\
\hline Cohesiveness & 0.733 & 0.951 & 0.795 & 0.337 & $\begin{array}{l}\text { Number of cells (-); Cell density(-); Small size(+); Large size (-); } \\
\text { Moisture (+); } \mathbf{L}^{*}(+) \text {; Weight }(+) \text {; Specific volume (-) }\end{array}$ \\
\hline Adhesiveness & 0.879 & 0.949 & 0.817 & 0.222 & Large size(-); L*(+); a*(-); BI (-); Weight(+); \\
\hline Crumb elasticity & 0.753 & 0.958 & 0.789 & 0.198 & $\begin{array}{l}\text { Number of cells (-); Cell density(-); Large size (-); } \mathbf{L}^{*}(+) ; \mathbf{a}^{*}(-) ; \mathbf{B I} \\
(-) \text {; Weight }(+) \text {; }\end{array}$ \\
\hline Shape recovery & 0.805 & 0.945 & 0.767 & 0.249 & Small size(-); L*(-); b*(-); BI (+); Weight (-); Specific volume (+) \\
\hline \multicolumn{6}{|l|}{ Aroma } \\
\hline Salty & 0.618 & 0.958 & 0.854 & 0.242 & Moisture(-); Specific volume (+); Salt (+) \\
\hline Sweet & 0.156 & 0.837 & 0.880 & 0.239 & - \\
\hline Bread aroma & 0.698 & 0.898 & 0.916 & 0.341 & Moisture(+); Weight (-); Specific volume (+) \\
\hline Aftertaste & 0.628 & 0.940 & 0.762 & 0.290 & $\begin{array}{l}\text { Number of cells (+); Cell density }(+) \text {; } \mathbf{L}^{*}(-) \text {; Weight (-); Specific } \\
\text { volume }(+)\end{array}$ \\
\hline Overall assessment & 0.067 & 0.415 & 0.250 & 0.720 & - \\
\hline
\end{tabular}

${ }^{\mathrm{T}}$ Latent variables with significant weight in the model and correlation with Y-variable; highly influential latent variables (variable importance for the projection $>1)$ are represented in bold and the remaining are moderately influential latent variables $(0.8<$ variable importance for the projection $<1)$. $(+)$, positive correlation with Y-variable;

(-), negative correlation with Y-variable. Latent variables were only considered for good models

BI, Browning index; Large size, Cell area $>10.0\left(\mathrm{~mm}^{2}\right)$; Medium size, $3.0<$ Cell area $\leq 10.0\left(\mathrm{~mm}^{2}\right)$; ns, not significant; Q2, cumulative predictive variation from internal cross-validation; $R^{2} X$, cumulative explained variation of $X$ explained in terms of sum of squares; $R^{2} Y$, cumulative explained variation of $Y$ explained in terms of sum of squares; RMSE, Root mean square error; Small size, $0.2<$ Cell area $\leq 3.0\left(\mathrm{~mm}^{2}\right)$; Very small size, Cell area $\leq 0.2\left(\mathrm{~mm}^{2}\right)$

The best fitting models for "Carcaça" bread (C) (Figure 1b) were the elliptical for $\mathrm{C} 1$ ( $\mathrm{p}=0.089)$, circular for $\mathrm{C} 2(\mathrm{p}=0.069)$, and vector for $\mathrm{C} 3(\mathrm{p}=0.078)$. In $\mathrm{C} 1$, the preference order was $\mathrm{C} 1.4>\mathrm{C} 1.0>\mathrm{C} 1.3>\mathrm{C} 1.1>\mathrm{C} 0.8>\mathrm{C} 0.0$. The circular model for $\mathrm{C} 2$ showed a maximum in terms of preference, known as the ideal point, with circular lines of isopreference drawn around it. Here, the preference order was $\mathrm{C} 1.4>\mathrm{C} 0.8>\mathrm{C} 1.1>\mathrm{C} 1.3>\mathrm{C} 1.0>\mathrm{C} 0.0$. For $\mathrm{C} 3$, preference order was $\mathrm{C} 0.8>\mathrm{C} 0.0>\mathrm{C} 1.4>\mathrm{C} 1.3>\mathrm{C} 1.0>\mathrm{C} 1.1$.

Considering "Mistura" bread (M) (Figure 1c), the vector model was the best fit for $\mathrm{C} 1(\mathrm{p}=0.020)$ and $\mathrm{C} 2(\mathrm{p}=0.071)$, while circular was the best for $\mathrm{C} 3(\mathrm{p}=$ $0.025)$. The preference order for this bread was M1.4>M1.1>M1.3>M1.0 > M0.8> M0.0 for C1 and C2, and M0.8>M1.0 > M1.4>M1.1>M1.3>M0.0. As for "Regueifa" bread (R) (Figure 1d), the vector model was the best fit for al clusters, but they were not significant $(\mathrm{p}>0.100)$. The preference order for the different clusters was $\mathrm{R} 1.4>\mathrm{R} 1.3>\mathrm{R} 0.8>\mathrm{R} 1.1>\mathrm{R} 1.0>\mathrm{R} 0.0$ for $\mathrm{C} 1 ; \mathrm{R} 0.8>$ $\mathrm{R} 1.4>\mathrm{R} 1.1>\mathrm{R} 1.0>\mathrm{R} 1.3>\mathrm{R} 0.0$ for $\mathrm{C} 2$; and $\mathrm{R} 1.4>\mathrm{R} 1.3>\mathrm{R} 1.0>\mathrm{R} 1.1>\mathrm{R} 0.8$ $>\mathrm{R} 0.0$ for $\mathrm{C} 3$.

Gathering the information from this analysis it was possible to establish the lowest salt concentration with better percentage of satisfied assessors (Figure 1) namely: $0.8 \%$ for "D'Água" (67\% of satisfied assessors) $0.8 \%$ for "Carcaça" (100\% satisfied assessors); $1.0 \%$ for "Mistura" (100\% satisfied assessors); and $1.1 \%$ for "Regueifa" ( $100 \%$ of satisfied assessors).

The results obtained suggest that higher salt reduction could have been attempted. However, considering the lack of data on salt reduction in Portuguese breads and respective consumers response, a conservative approach was chosen (salt reduction up to $40 \%$ )

\section{Correlation of sensory characteristics with physicochemical parameters}

PLS regression model quality was performed to establish a simultaneous correlation between sensory attributes and analytical parameters: physicochemical parameters (weight, specific volume, moisture, salt concentration, crumb structure, and colour). This model is based on sensory data prediction (Y-variables) from analytical parameters data (X-variables). For a successful regression model, the values obtained for $R^{2} Y$ and $R^{2} X$ must be equal or superior to 0.7 and the prediction ability is achieved by $\mathrm{Q}^{2}$ values, which must be equal or superior to 0.5 .
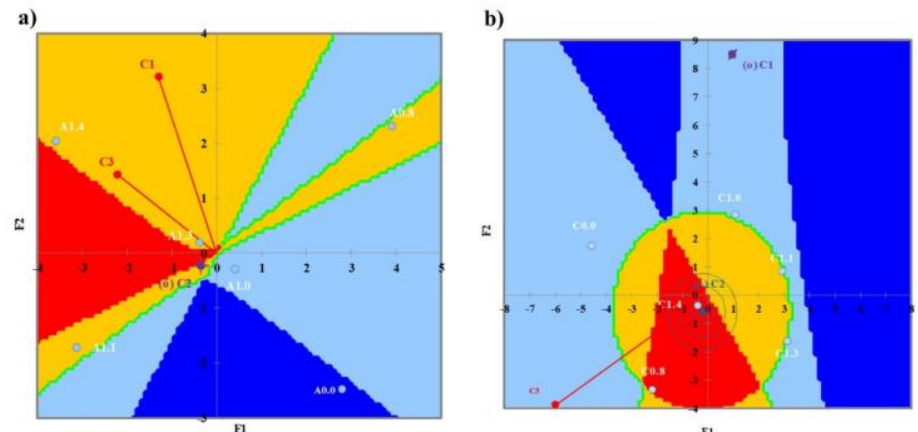

c)

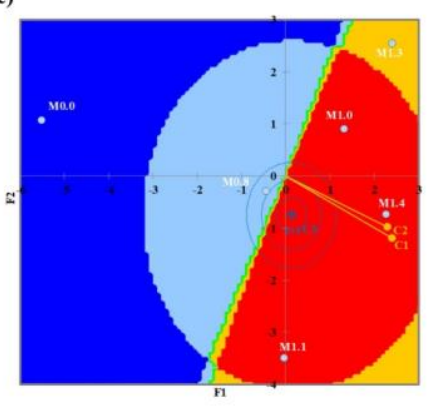

d)

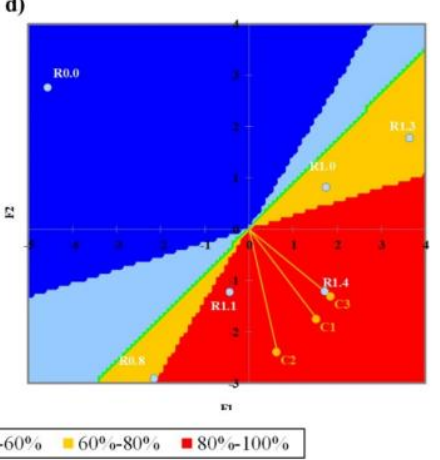

Figure 1 External preference mapping for a) "D’Água", b) "Carcaça", c) "Mistura", and d) "Regueifa" breads.

3 clusters are illustrated: 1 and 3 (vector), and 2 (elliptical (०); where the circle indicates a point of low variability in preference, located immediately before a decrease or increase in preference area) and the 5 regions of the global average value of acceptance.

0.0 , Breads with $0.0 \%$ salt; 0.8 , Breads with $0.8 \%$ salt; 1.0 , Breads with $1.0 \%$ salt; 1.1 , Breads with $1.1 \%$ salt; 1.3 , Breads with $1.3 \%$ salt; 1.4 , Breads with 
1.4\% salt; A, "D’Água" bread; C, "Carcaça"; C1, Cluster 1; C2, Cluster 2; C3, Cluster 3; M, "Mistura"; R, "Regueifa".

Table 6 summarizes individual sensory attributes prediction models from analytical parameters. Of the 17 sensory attributes analysed, 9 were found to be correlated with analytical parameters. Overall, models with good predictive quality were obtained for crust colour intensity, crumb colour intensity, cohesiveness, adhesiveness, crumb elasticity, shape recovery, salty, bread aroma, and aftertaste. These results indicate that, at some extent, assessors were able to evaluate the parameters evenly, regardless of the type of bread analysed. As for the attributes with lower quality values, they can be explained by a dispersion in the results, which may indicate that these parameters were considered in different ways for each type of bread. Consequently, the mathematical base cannot produce a model with good predictive quality.

The importance of $\mathrm{X}$-variables (analytical parameters) in the projection and their correlation with Y-variables (sensory attributes) was also determined, and latent variables were identified (Table 6). Moreover, analytical parameters common in regression models with good performance for each group of sensory attribute were identified. Regarding appearance attributes, crust and crumb colour were more intense for redder and browner breads, and less intense for darker breads As for appearance attributes related to crumb structure, models were poorly fitted $\left(\mathrm{R}^{2} \mathrm{Y}\right.$ and $\left.\mathrm{R}^{2} \mathrm{X}<0.50\right)$, and with poor $\left(0.00<\mathrm{Q}^{2}<0.50\right)$ or lacking $\left(\mathrm{Q}^{2}<0.00\right)$ predictive ability. Odour and texture characteristics were not evaluated analytically, and therefore, it would be less likely to find correlations or successful predictive model for these parameters. Although models for odour intensity and crunchy crust models were poorly fitted $\left(\mathrm{R}^{2} \mathrm{X}<0.50\right)$ and with poor $\left(0.00<\mathrm{Q}^{2}<0.50\right)$ predictive ability, it was possible to find good predictive models for other texture attributes, namely cohesiveness, adhesiveness, crumb elasticity and shape recovery. Lighter and heavier breads were the ones with higher cohesiveness, adhesiveness, and crumb elasticity, but also with lower shape recovery. Moreover, breads with higher percentage of large size cells were less cohesive, adhesive, and with lower crumb elasticity. Regarding aroma sensory attributes, breads with higher specific volume were saltier and with higher bread aroma and aftertaste. Furthermore, it was interesting to observe that saltier breads were the ones with higher salt concentration, as it would be expected. As regards to sensory attribute overall assessment, no association models with good fitting and predictive ability were found. This sensory attribute, unlike others, is more susceptible to a subjective evaluation and therefore, is a more difficult to standardize. Globally, these results could be expected at some extent nevertheless, it is important to highlight that they show associations and not cause-effect relationships.

\section{CONCLUSION}

Salt reduction in the different bread formulations had limit impact on physicochemical and sensory characteristics. Results obtained from the consumer test only showed significant differences for salt reduction with taste liking and overall linking attributes. Mathematical modelling was shown as a relevant tool to study bread acceptability and understand relationships between sensory and analytical data. External preference mapping was appropriate to study consumer preferences and to select the lowest salt concentration with best acceptance, namely $0.8 \%$ for "D'Água"; $0.8 \%$ for "Carcaça"; $1.0 \%$ for "Mistura"; and $1.1 \%$ for "Regueifa". The results suggest that it is possible to reduce, to some extent, the salt concentration in all bread types without major impact on bread characteristics and without compromising consumers' acceptance.

Additionally, PLS regression provided information on the relationship between sensory and analytical data (physicochemical). Successful models were obtained for crust colour intensity, crumb colour intensity, cohesiveness, adhesiveness, crumb elasticity, shape recovery, salty, bread aroma, and aftertaste. However, these relationships should be interpreted as associations and not as direct cause and effect, once observed correlations do not necessarily imply causality.

Acknowledgments: The CIAFEL is supported by FCT/ UIDB/00617/2020. The CITAB is supported by FCT/ UIDB/04033/2020. Zita Martins acknowledge PTDC/OCE-ETA/32567/2017 for her research contract.

\section{REFERENCES}

AACC International. (1999). AACC International Approved Methods - AACC Method 44-15.02. Moisture -- Air-Oven Methods. http://methods.aaccnet.org/summaries/44-15-02.aspx

Antúnez, L., Giménez, A. \& Ares, G. (2016). A consumer-based approach to salt reduction: Case study with bread. Food Research International, 90, 66-72. https://doi.org/10.1016/j.foodres.2016.10.015

Assembleia da República. (2009). Lei $n .^{\circ} 75 / 2009$ de 12 de agosto. Diário da República: I $\quad$ Série, ${ }^{\circ}$ 155/2009. https://data.dre.pt/eli/lei/75/2009/08/12/p/dre/pt/html

Beck, M., Jekle, M., \& Becker, T. (2012). Impact of sodium chloride on wheat flour dough for yeast-leavened products. II. Baking quality parameters and their relationship. Journal of the Science of Food and Agriculture, 92(2), 299-306. https://doi.org/10.1002/jsfa.4575

Belz, M. C., Ryan, L.A., \& Arendt, E. K. (2012). The impact of salt reduction in bread: a review. Critical Reviews in Food Science and Nutrition, 52(6), 514-524. https://doi.org/10.1080/10408398.2010.502265

Buera, M., Petriella, C., \& Lozano, R. (1985). Definition of colour in the nonenzymatic browning. Farbe, 33, 316-326.

European Union. (2009). National Salt Initiatives. Implementing the EU Framework for salt reduction initiatives. https://ec.europa.eu/health/sites/health/files/nutrition physical activity/docs/salt report1_en.pdf.

Greenhoff, K, \& MacFie, H. J. H. (1994). Preference mapping in practice. In MacFie, H. J. H, \& Thomson D MH (Eds.), Measurement of food preferences (pp. 137-166). Boston, MA: Springer US.

Ishii, R., Kawaguchi, H., O’Mahony, M., \& Rousseau, B. (2007). Relating consumer and trained panels' discriminative sensitivities using vanilla flavored ice cream as a medium. Food Quality and Preference, 18(1), 89-96. https://doi.org/10.1016/j.foodqual.2005.08.004

International Organization for Standardization. (2012). ISO 8586:2012 Sensory analysis-general guidelines for the selection, training and monitoring of selected assessors and expert sensory assessors. (ISO standard No. 8586:2012). https://www.iso.org/standard/45352.html

Lynch, E. J., Dal Bello, F., Sheehan, E. M., Cashman, K. D., \& Arendt, E. K. (2009). Fundamental studies on the reduction of salt on dough and bread characteristics. Food Research International, 42(7), 885-891. https://doi.org/10.1016/j.foodres.2009.03.014

Lopes C, Torres D, Oliveira A, Severo M, Alarcão V, Guiomar S, ... \& Ramos E. (2018). National Food, Nutrition, and Physical Activity Survey of the Portuguese General Population, IAN-AF 2015-2016: Summary of Results. ISBN: 978-989746-202-3. www.ian-af.up.pt

Man, C. (2007). Technological Functions of Salt in Food Products. In A.F. Kilcast D. (Ed.), Reducing Salt in Foods: Pratical Strategies (pp. 157-173). Cambridge. https://doi.org/10.1533/9781845693046.2.157

Martins, Z., Erben, M., Gallardo, A., Silva, R., Barbosa, I., Pinho, O., \& Ferreira, I. (2015). Effect of spent yeast fortification on physical parameters, volatiles and sensorial characteristics of home-made bread. International Journal of Food Science and Technology, 50(8), 1855-5163. https://doi.org/10.1111/ijfs.12818

Martins, Z., Pinho, O., \& Ferreira, I. (2017). Fortification of Wheat Bread with Agroindustry By-Products: Statistical Methods for Sensory Preference Evaluation and Correlation with Color and Crumb Structure. Journal of Food Science, 82(9), 2183-2191. https://doi.org/10.1111/1750-3841.13837

Matz, S.A. (1992). Bakery Technology and Engineering. New York: Van Nostrand Reinhold

McCann, T.H., \& Day, L. (2013). Effect of sodium chloride on gluten network formation, dough microstructure and rheology in relation to breadmaking. $\begin{array}{llll}\text { Journal of Cereal Science, } & 57(3), & 444-452\end{array}$ https://doi.org/10.1016/j.jcs.2013.01.011

Miller, R.A., \& Hoseney, R.C. (2008). Role of salt in baking. Cereal Foods World, 53(1), 4-6. https://doi.org/10.1094/cfw-53-1-0004

Poggio, R., Gutierrez, L., Matta, M.G., Elorriaga, N., Irazola, V., \& Rubinstein, A. (2015). Daily sodium consumption and CVD mortality in the general population: systematic review and meta-analysis of prospective studies. Public Health Nutrition, 18(4), 695-704. https://doi.org/10.1017/s1368980014000949

Polónia, J., Martins, L., Pinto, F., \& Nazaré, J. (2014). Prevalence, awareness, treatment and control of hypertension and salt intake in Portugal: changes over a decade. The PHYSA study. Journal of Hypertension, 32(6), 1211-1221. https://doi.org/10.1097/hjh.0000000000000162

Powles, J., Fahimi, S., Micha, R., Khatibzadeh, S., Shi, P., Ezzati, ... \& Mozaffarian, D. (2013). Global, regional and national sodium intakes in 1990 and 2010: a systematic analysis of $24 \mathrm{~h}$ urinary sodium excretion and dietary surveys worldwide. BMJ Open, 3(12), e003733. https://doi.org/10.1136/bmjopen-2013$\underline{003733}$

Rødbotten, M., Tomic, O., Holtekjølen, A. K., Grini, I. S., Lea, P., Granli, B. S., \& Sahlstrøm, S. (2015). Barley bread with normal and low content of salt; sensory profile and consumer preference in five European countries. Journal of Cereal Science, 64, 176-182. https://doi.org/10.1016/j.jcs.2015.05.001

Silow, C., Axel, C., Zannini, E., \& Arendt, E.K. (2016). Current status of salt reduction in bread and bakery products - A review. Journal of Cereal Science, 72, 135-145. https://doi.org/10.1016/j.jcs.2016.10.010

Skendi, A., Biliaderis, C.G., Papageorgiou, M., \& Izydorczyk, M.S. (2010). Effects of two barley $\beta$-glucan isolates on wheat flour dough and bread $\begin{array}{llll}\text { properties. Food Chemistry, } & 119(3), & 1159-1167 .\end{array}$ https://doi.org/10.1016/j.foodchem.2009.08.030

Vieira, E., Soares, M.E., Ferreira, I., \& Pinho, O. (2012). Validation of a Fast Sample Preparation Procedure for Quantification of Sodium in Bread by Flame Photometry. Food Analytical Methods, 5, 430-434 https://doi.org/10.1007/s12161-011-9247-8

WHO. (2012). Guideline: Sodium intake for adults and children. WHO, Geneva http://www.who.int/nutrition/publications/guidelines/sodium intake printversion 